\title{
The importance of separating national and international arbitration in Iranian and UNCITRAL law
}

\author{
Seyed Mohammad Asadi nejad \\ (asadinezhad@guilan.ac.ir), \\ Associate Prof., department of Law, Faculty of Literature and Humanities, University of Guilan, Rasht, Iran
}

Seyedeh Maryam Asadinejad

(sm.asadinejad@ahrar.ac.ir),

Medical doctor, Faculty Member, Law Department ,Ahrar Institute of Technology and Higher Education ,

Rasht,Iran

\begin{abstract}
International arbitration is a solution to resolve disputes between persons due to the existence of a communication element International is distinguished from national arbitration rules.International title on international arbitration may make this impression that International arbitration is a nascent institution, while a review of past literature reveals that It has been an institution of the past. Therefore, national arbitration is different from international arbitration. What factors This article examines the factors that lead to the internationalization of arbitration. Normally, in any case, the slightest communication factor may cause conflict of laws, This highlights the need for international commercial arbitration .For this reason, the UNCITRAL Model Arbitration Law has introduced a large number of communication factors that are subject to international arbitration for countries.However, in Iranian law, the distinction between national arbitration and international arbitration, contrary to the UNCITRAL Model Law, is achieved simply by the International Commercial Arbitration Law of Iran and simply by having different nationalities of the parties.In other words, the legislator has introduced citizenship as the only communication factor that causes the inclusion of Iran's international commercial arbitration law. This causes most arbitrations to be subject to national arbitration so that the parties have limited freedom and cannot use the rules of international commercial arbitration even by mutual agreement.In this article, the factors that are based on the model law The internationalization of arbitration has been examined and their non-inclusion in commercial arbitration regulations Will be examined internationally and then interact with the Convention on the Recognition and Enforcement of Arbitral Awards New York 1985 will be analyzed.
\end{abstract}

Keywords: International Arbitration, National Arbitration, foreign Arbitration, Communication Elements.

DOI: $10.7176 / \mathrm{JLPG} / 110-14$

Publication date:June $30^{\text {th }} 2021$

Introduction

The angles of international arbitration and its dimensions are still unknown due to lack of careful study. Some features of international arbitration, including the privacy of the arbitration agreement and the principle of independence of the arbitration clause from the main contract.It has caused a distinction from domestic regulations so that the side effects of these matters have led to the transformation of arbitration, both national and international arbitration.One of the most important benefits of arbitration is the rapid attainment of superior justice and the issuance of a final judgment.Failure to refer to the courts of the country of the parties and refer to impartial arbitrators are the minimum benefits of arbitration.It is obvious that concluding an arbitration agreement in any form and in any kind of contract and culture in this field will not only reduce the number of cases in the courts.Rather, in the international arena, it prevents the conflict of jurisdiction of the courts of different countries.In addition, the verdict will be easily enforceable, and in most cases, the season of hostility through arbitration is such that it does not sever the relationship between the parties.Obviously, domestic 
arbitration is different from international arbitration and has different effects.So the main question is what are the factors that differentiate domestic arbitration from international arbitration?Is foreign arbitration the same as international arbitration or is it part of domestic arbitration?To address these issues, the internationalization standard of arbitration in the UNCITRAL Model Law is also analyzed.To do this, the UNCITRAL Model Arbitration Law, according to which Iran's International Commercial Arbitration Law was formed Also, some regulations of other countries will be reviewed and analyzed.Also, some regulations of other countries will be reviewed and analyzed.Obviously, the distinction between international arbitration on the one hand and national arbitration as well as foreign arbitration on the other has its own effects. This difference will become apparent by examining the functioning of the provisions of the 1985 Convention on the Identification and Enforcement of Arbitral Awards.It should be noted that the accession to this convention, dated April 21, 1380, was approved by the Islamic Consultative Assembly and approved by the Guardian Council on 1380.1.29.

\section{1- History of International Arbitration and International Arbitration Agreement:}

It is always thought that any legal title with an international suffix is a new topic related to new civilizations, while this is not true by examining ancient texts.Judgment has been in all ages. This distinction is made by examining the background of international arbitration as well as the origin of international arbitration, which is in fact the arbitration agreement.

\section{1-1- Background of International Arbitration}

As mentioned, international arbitration is not specific to the present era, but has been one of the oldest methods of resolving international disputes in the past.For example, in ancient Greece and in ancient Rome, China and ancient Iran, among the Phoenicians (in Mesopotamia), one can clearly see signs of international arbitration.In China, from 1600 to $2100 \mathrm{BC}$, which was influenced by the school of Confucius, and also in ancient Rome, international arbitration was used to resolve disputes between governments and quasi-governmental institutions, as well as city governments ${ }^{1}$.

.During the pre-Islamic period, differences between different tribes, each with its own profession and sect, which was not ruled by any country or kingdom, used the judgment of neutral individuals.Disputes were resolved between tribes, including the Bani Nadir tribe and other tribes. Also, the judgment of the Holy Prophet (PBUH) when he was 35 years old to place the Black Stone resolved the dispute between the two tribes. ${ }^{2}$ Also, the arbitration of Sa'd ibn Mu'adh in relation to the tribes of Bani Qurayzah and Aws was in fact an international arbitration.Or the story between Ali (AS) and Mu'awiyah between Kufa and Damascus in the battle of Safin in $37 \mathrm{AH}$ after Mu'awiyah's troops were defeated by Ali's troops.He resorted to clever tricks and speared the Qurans and demanded the wisdom of the Qur'an, and Ali (AS) inevitably accepted the wisdom.All of this in a way expresses international arbitration. In addition, verses in the Qur'an, including the following verse, indicate international belief.

"But no, by your Lord! They will not believe until they make you a judge in their disputes, then do not find within their hearts any dissent to your verdict and submit in full submission." 3

But no, by your Lord, they will not believe until they accept you [O Prophet] as judge in their disputes, and find no discomfort within their hearts about your judgments, but accept them wholeheartedly.

There was a dispute between Zubair ibn Awwam, one of the emigrants, and one of the Ansar, over the irrigation of the grove.The Ansari man was upset with the Prophet's judgment and said, "Because Zubair is your cousin, you judged in his favor!"

The color of the Prophet jumped and this verse was revealed. It is strange that they themselves have accepted the Messenger of God as a judge, but they refuse. ${ }^{4}$ As can be seen, such differences between two tribes are in fact differences between two governments and two separate territories. In addition, it refers to this verse and includes any differences, whether domestic or international.The concept of arbitration agreement and the law governing it:An arbitration agreement is also called an arbitration agreement.Of course, the arbitration agreement or arbitration agreement may be mentioned as a condition in another original contract, which is called an arbitration condition or consolidation condition.Paragraph c of Article 1 of the International Commercial Arbitration Law of Iran, which refers to both forms of arbitration agreement, provides:

1 - Greek city states.

2 - Davani, Ali (1980) History of Islam, Haghayegh Publications, Qom,p.75.

3 - Verse 65, Surah An-Nisa '.

4 - Qaraati, Mohsen (2009) Tafsir Noor, vol. 2, Cultural Center for Quranic Lessons, Tehran ,p. 321. 
The arbitration agreement may be a condition of arbitration in the contract or in a separate contract.

Article 455 of the Code of Civil Procedure also stipulates:

The parties to the transaction may be required to enter into a transaction or, under a separate contract, to refer to arbitration in the event of a dispute between them.

They can also appoint their own arbitrator or arbitrators before or after the dispute. The second paragraph of Article 2 of the New York Convention also refers to both: the term written agreement shall include the arbitration clause in the arbitration agreement or agreement signed by the parties in writing or include an exchange letter or telegram.Of course, most cases of referral to arbitration in national arbitration are a condition of arbitration, and even the same trend prevails in international arbitration.For example, of the 273 cases referred to the International Chamber of Commerce Arbitration Court in 1987, only 4 were based on an arbitration agreement or arbitration agreement. ${ }^{1}$ In any case, an arbitration contract, like any contract, is a legal act that is created by the agreement of at least two wills, and its purpose is the obligation to resolve the dispute through private arbitration, ie arbitration.Arbitration agreement, like the main contract, is concluded in the first place based on the rule of will and according to the law determined by the parties. In the absence of such a choice, the main tendency is towards the law of the place of arbitration. ${ }^{2}$ And in many lawsuits, local law has been used.$^{3}$ In some cases, the local law that is most closely related is known as the governing law . As mentioned, instead of using the arbitration agreement, the legislator has used the agreement which includes the arbitration clause and the arbitration agreement, so the arbitration clause, because it is part of the main contract, is in fact part of the contract and is binding on both parties.

There is no dispute between the parties and it does not lead to the appointment of an arbitrator.Therefore, it seems based on Articles 455, 460, 464 and 458 of this civil procedure. There is no difference between the arbitration clause and the arbitration contract in terms of appointing and not appointing an arbitrator.That is, there is no need to appoint an arbitrator, neither in the arbitration condition nor in the arbitration contract.Article 458 - In any case in which an arbitrator is appointed, the subject and duration of the arbitration, as well as the characteristics of the parties and the arbitrator or arbitrators, shall be determined in such a way as to eliminate the error.If the arbitrator is appointed after the dispute has arisen, the subject matter of the dispute referred to arbitration must be clearly identified and communicated to the arbitrators.However, the distinction between the arbitration clause and the arbitration agreement is contrary to the opinion of some authors. ${ }^{4}$ However, the distinction between the arbitration clause and the arbitration agreement is contrary to the opinion of some authors ${ }^{5}$. There is no substantive difference according to Article 458, so that non-observance of it does not invalidate the arbitration. The legislator has facilitated the arbitration clause during the contract and has not considered the precise determination of the subject of arbitration and the appointment of the arbitrator as a condition for the validity of the arbitration clause. While in French law, failure to appoint an arbitrator or failure to arrange the selection of an arbitrator invalidates the arbitration requirement ${ }^{6}$.Articles 1442 and 1447 of the French Code of Civil Procedure are apparently between the arbitration clause before the dispute arises

And the arbitration contract that is settled after the dispute has been settled, so that in the arbitration contract, certain special conditions, such as determining the subject of arbitration, are considered necessary.

Also, according to Article 1443, in the condition of arbitration, an arbitrator must be appointed, while in French international arbitration, not appointing an arbitrator does not invalidate the arbitration. ${ }^{7}$ It should be noted that the arbitration agreement should not be confused with the arbitration letter.The arbitration letter is a strategic document that is the guiding light for the arbitrators to review, but the arbitration agreement is the arbitration agreement. Arbitration is not required to be prepared contrary to the arbitration agreement, but if it is regulated, it must be acted upon because the arbitration is a document based on which the limits of authority and description of the duties of arbitrators are determined. ${ }^{8}$ Arbitration Letter from the Innovation Rules of the International Chamber of Commerce as provided in Article 23: The Arbitration Board shall prepare a document

\footnotetext{
1 - Bond,R Stephen(1989) . How to draftan arbitration clause ,J.Int.Arb.No2, P.6.

2 - Sidi, Javad, 2013, An Introduction to Referendum Ability in International Commercial Arbitration, Jangal Publications, First Edition, Tehran ,p. 12.

3 - Lew.j.d.m and ali (2003) comparative international commericaialarbitration .klawer law international,p.203.

4 - Karimi, Abbas, Parto, Hamidreza, (2012) Internal Arbitration Law, Nashrdadgostar, Tehran,p.105.

5 -Ibide, 2012.

6 - Art 1443 New code.

7 - Kalantarian, Morteza (1995) Arbitration: A Study of the Most Important Legal Arbitration Systems in the World, Legal Services Office of the Islamic Republic, Tehran,p.218.

8 - Mohebbi, Mohsen (1988) Execution of Foreign Arbitration Rulings, Legal Services Office, Tehran ,p.103.
} 
based on the documents or in the presence of the parties or according to the latest bills submitted by them and determine its duties.

National arbitration

However, before defining domestic or national arbitration.International arbitration must first be considered as an exception. However, first the concept of arbitration and then the concept of national arbitration are examined.Arbitration is equivalent to arbitration and consolidation. The arbiter is basically the owner of the lawsuit, which has become the arbiter due to the multiplicity of uses, and means judging and ruling between two enemies (Dehkhoda, Dictionary, following arbitration).

Arbitration and consolidation, which is the root of the ruling, means to judge and adjudicate, and in principle, it means to forbid and detain. ${ }^{1}$ There are many definitions of arbitration, each of which in its own position greatly clarifies the nature of arbitration.For example, it is said that the season of hostility is judged by one or more nonjudges without observing the formalities of litigation. ${ }^{2}$ It has also been argued that arbitration actually excludes individuals from interfering with official authorities in resolving claims relating to their private rights and surrendering them to the private government of persons who are their most trusted in terms of information and technical knowledge or reputation for salvation and trust. ${ }^{3}$ It is also said that arbitration is the referral of a dispute to a selected third party who agrees to a post-trial vote and an opportunity for defense by the arbitrator. ${ }^{4}$ Arbitration is not defined in the National Arbitration Law, ie the Civil Procedure Code, but in an article of the International Commercial Arbitration Law of Iran approved in 1997, arbitration is defined.Although this definition of arbitration is absolute and includes national and international arbitration, because the international element is not included in it, it is more similar to the definition of national or domestic arbitration:

Arbitration is the resolution of disputes between defendants outside the court by a person or natural and legal persons who are pleasing to the parties or by appointment, although in most cases this law has been adapted from the UNCITRAL Model Law.But our legislator, despite the lack of definition of arbitration in the UNCITRAL Model Law, has defined it without mentioning the existence of an external element.In fact, this definition is absolute and can negligently include international arbitration. However, this definition has been carefully adjusted for the types of judges and their position, which is explained as follows:

1-Arbitration may be referred by one or more natural or legal persons. In fact, it also refers to arbitration organizations, although in the end arbitration will be done by representatives of legal entities. The arbitration may be conducted by an individual arbitrator or may be performed by a number of arbitrators.

2. The arbitrator may be mutually agreeable, ie appointed by the parties and by consensus, or the appointing authority, including the court of justice, may be so-called appointed in cases where there is a dispute between the parties regarding the appointment of an arbitrator.

3-Referral to arbitration with the agreement or without the agreement of the parties. Given that the above definition does not refer to the agreement of the parties to refer the matter to arbitration instead of referring to the court of justice, so the definition can include both optional arbitration and compulsory arbitration. Compulsory arbitration is like arbitration according to the law of the securities market.

It seems that in the logical definition of arbitration, one should pay attention to its gender and chapter, and also based on the main elements of arbitration, which are the contract of arbitration and the parties to the dispute, their differences and arbitrators, as well as the judicial nature and binding nature of arbitration. And a lawsuit was considered. According to this goal, we can say:

Arbitration is the settlement of a dispute by virtue of a private contract or by law through the consideration and issuance of a judgment by the person or persons surrounding the dispute with Choose a conciliation or are chosen by the judicial or quasi-judicial authorities on behalf of the litigants in accordance with the law.However, regarding the concept of national or internal arbitration, it should be said that basically if there is no external element in the contract or agreement concluded between the parties, such arbitration is internal or national and will be included in the Code of Civil Procedure.And the vote is also considered domestic and such a vote will be fully protected by domestic law.Of course, we will see that in some cases, although there is an external element, but the internal vote is not external.That is, although it may have been an international arbitration, it is

1 - Qayyumi, Al-Misbah Al-Munir,vol 2,p.145.

2 - Jafari Langroudi, Jafar (2006) Terminology of Law, Treasure and Knowledge, Tehran , p.138- 284.

3 - Matin Daftari, Ahmad, (1970) Civil and Commercial Procedure, Volume One, Tehran ,p. 120.

4 - Combpell Black Henry(1968), Blacks Law Dictionary minnessota, 198, p.29. 
considered an internal ruling and is easily enforced in the domestic courts of the country where the ruling was issued.It should be noted that it is essential to determine whether the arbitration is national or international, because if it is determined that the arbitration is international.In this case, the subject matter and the rule of law will be subject to the International Commercial Arbitration Law 76, but if there is no international element and the subject of internal arbitration is the provisions of the Code of Civil Procedure will prevail.In a more general view of the effects of the distinction between national and international arbitration, it should be said that international arbitration should contain more flexible rules in order to safeguard the interests of traders and trade relations and the development of international trade.Therefore, in order to preserve the interests and creativity of different nations, as well as in order to standardize the arbitration rules, it is necessary that the international arbitration rules be separated from the domestic arbitration rules and that all countries have almost the same international arbitration rules.International Arbitration Prior to the enactment of the International Commercial Arbitration Law in 1997, we could argue that the provisions of the Code of Civil Procedure, with the exception of some provisions relating to the appointment of arbitrators by the courts and arbitration of disputes arising from other rules of civil procedure in accordance with commercial arbitration Has not been international or even arbitrated in countries. ${ }^{1}$

Although the Code of Civil Procedure has a reason for comment in domestic arbitration, but in any case, after the approval of the International Trade Arbitration Law of Iran in 1976, the territory of this law has been made completely transparent by the Code of Civil Procedure.Basically, it is very important to determine whether the arbitration is national or international, because if it is determined that the arbitration is international.In this case, the subject matter and the rule of law will be subject to the International Commercial Arbitration Law, 76 but if there is no international element and the subject matter is domestic arbitration, the provisions of the Code of Civil Procedure will prevail. Therefore, it is important to distinguish international arbitration from national and domestic arbitration. Therefore, in domestic disputes, we can not use the International Commercial Arbitration Law 76 because the agreement of individuals in this regard will be contrary to public order and the rules of jurisprudence.

\section{1-3- Foreign arbitration}

External arbitration is not equivalent to international arbitration. As we will see, the existence of an international element may have led to the realization of international arbitration, but foreign arbitration is not. For example, an arbitration conducted in Iran is a foreign arbitration in the eyes of the Turkish courts, whether commercial or non-commercial arbitration, although such an arbitration is sponsored by the New York Convention and is easily enforced in the countries of the country that accede to the Convention. These have been implemented.In fact, according to Article 1 (1) of the New York Convention, a verdict issued in a country other than the country of implementation, although not subject to international arbitration, but because a foreign vote $^{2}$ and is considered a foreign arbitration. Becomes. The Convention also applies to votes which are not in accordance with the regulations of the place of export and which wish to be implemented in the same country. Despite all these mechanisms, such arbitration still has no international character, but is an external arbitration. Of course, in some cases, arbitration may be due to the fact that it is not an Iranian citizen and is an international arbitrator and is subject to the International Commercial Arbitration Law of Iran, but if it is the place of execution of the ruling in Iran, such arbitration is considered domestic. Therefore, when an arbitration award is issued in a country other than the place of execution, the arbitration will be foreign.

\section{1-4- Internationalization of Arbitration Criteria}

As mentioned, the existence of an external element, just as it causes the internationalization of any contract, is also the case in arbitration, which is considered a contract. But what elements will lead to the internationalization of arbitration.It should be noted that from the point of view of private international law, many factors and elements can cause a possible connection and give the arbitration an international character. Factors such as the following factors can be involved:

1- Nationality or residence of the arbitrator or arbitrators

2. The nationality of the parties to the dispute

\footnotetext{
1 - Nasiri, Morteza (1964) Execution of foreign arbitral awards, Mousavi Publications ,p. 221.

2 - Junidi, Laia (2013) Execution of foreign commercial arbitration rulings, its mayor, Tehran, p. 502.
} 
3- The residence or important center of the parties or the center and place of business of the parties or the company

4. Venue

5. Location of the parties

Other factors related to the nature of the dispute, such as:

6- Place of concluding the contract

7. Place of contract execution

8. The place where the property is located

9- The place where the loss occurred

10. Foreign law governing arbitration

11- Foreign law governing the original contract and arbitration agreement

12- The law governing the arbitration procedure and the nature of arbitration

Obviously, if all these cases and related factors are related to the country and the legal system of a country, then it is a national arbitration and the domestic law of that country is applied.Among all the communication factors, there are two very important communication factors: one is the law chosen by the parties, which is also based on the contractual nature of arbitration, and the other is the consideration and results obtained at the place of arbitration. ${ }^{1}$ However, each country and convention typically provides for the existence of an international element in international arbitration rules, for example, residence in the European Convention on Commercial Arbitration and residence in Swiss private international law, or in Sweden, if the place of arbitration is in another country. In France, if the subject is in the interests of international trade, the criterion for international recognition is arbitration.

2. Article 1 (1) (a) The European Convention on Arbitration for International Trade shall establish both place of residence and domicile. -2-Europen Convention on International Commercial Arbitration1961.Art.1.1 (a): Their habitual place

of residence or their seat in different Contracting states.

Article 1492 of the French Code of Civil Procedure provides in this regard: "Arbitration is international when it is related to international commercial interests".

It is similar to Article 458 of the Algerian Code of Civil Procedure 1993, which makes the interests of international trade the criterion: "It is considered international." Restrictions on the interests of international trade make arbitration known as international arbitration because of its minimal connection to international trade, even if the parties are not foreign nationals or have not traded abroad.In fact, the most objective communication factor based on the international nature of the dispute is the dispute, which is clearly stated in French law and very clearly in Article 458 of the Algerian Code of Civil Procedure, so that the nationality of the litigants and even the place of arbitration play an international role. There is no arbitration.It seems that such an attitude and consideration of such rules can lead to the development of trade and economic prosperity and the removal of barriers in any country because it expands the scope of international arbitration and thus causes the issue of internal arbitration to be strictly regulated. It is more compelling than international arbitration.Also, in many cases, the shadow of domestic court oversight is removed or reduced by international arbitration. However, because such a definition of the international concept by the French legislature is very broad in substance and leads to different interpretations in the courts of different countries where the provisions of the model law were accepted, the working group of drafters of the model law at the time of drafting the criteria and property French

1 - Gillard, Emmanuel,\& savage John,(1999), , fouchardGillard,goldman on jnternatinal commercialarbitrational,kluwer law international,p.56. 
international arbitration was left out and ignored. ${ }^{1}$ For this reason, the text of the 1961 Geneva Convention on International Commercial Arbitration was originally considered to be the source of inspiration for the drafters of the Model Law ${ }^{2}$ in that it made arbitration an international criterion for the place of business of litigants in different countries. Of course, the criterion of different business location of the parties is one of the most important factors in the international nature of arbitration was included in the model law. Other cases intended for the internationalization of arbitration also have a special legal status.

In general, the drafters of the UNCITRAL Model Law have tried to provide standard criteria for harmonizing the laws of the countries in order to be welcomed by most countries. Provides the following:Arbitration is international if (a) the place of business of the parties to the arbitration agreement at the time of its conclusion in the countries. Are you different?

(B) is one of the sub-locations of the country in which the place of business of the parties is situated; (a) the place of arbitration if specified in the arbitration agreement or by it; The place where the subject matter of the dispute relates most closely to (c) the parties have expressly agreed that the subject matter of the arbitration agreement relates to more than one country.

Therefore, according to the above article, the criteria for international arbitration are:

1- Business place: Existence of business place of the parties in two different countries.

2- Arbitration place: The place of arbitration or the place of arbitration is outside the place of business of the parties.

3-Place of execution of the bulk of the obligations: If the place of execution of the bulk of the obligations is in a different country from the country where the place of business is located.

4- Relationship of the subject of dispute: If the subject of the dispute has the closest connection with that place which is different from the place of trade and transaction of Anhavia or even a different country from the place of arbitration.

5. Explicit agreement of the parties: If the parties have specified that the subject of the arbitration agreement is related to a country other than the country where the place of business or place of arbitration is.

Regarding the first criterion and criterion of the model law, ie the place of business of the parties, because it is a criterion that is related to the parties, in this respect it is related to the subject of the criterion of citizenship of the parties because this criterion goes back to the parties.

According to paragraph 1, if at the time of concluding the arbitration agreement, the place of business of the parties is different, such arbitration will be international commercial arbitration, although after the conclusion of the arbitration agreement, the place of arbitration of the parties will be the same. Place of business or transaction in commercial and even civil law is the most important criterion in many cases because custom, which is always the language of esoteric will or tacit agreement of the parties, is the custom of business place, so that even if the parties are ignorant of the content of custom and habit. In the event of a contractual vacuum, the custom of the place of business is considered the main criterion for resolving the dispute.Regarding the second criterion and criteria, ie the place of arbitration or the place of arbitration that is outside the place of business of the parties, it should be said that according to the UNCITRAL rules in case of arbitration (Adhoc), the place of arbitration must be specified. It is best to state the decision in the arbitration case.

The authority and freedom of the parties to determine the place of arbitration is mentioned in almost all arbitration rules and regulations, including in paragraph 1 of Article 20 of the Law on Arbitration, even in organizational arbitration, the parties will have such authority.Arbitration place or headquarters is not in the sense of physical location but has a credit aspect. This issue is well understood from Article 20 of the Model Law and our law, because firstly, the location is given to the parties. The circumstances of the dispute and the ease of access of the parties are determined by the arbitrators. This indicates that the place of arbitration is not necessarily the physical place or the place where the most meeting took place, but the legal criterion means that the place of arbitration may be a place agreed upon by the parties. Without even having a meeting there. In addition, the place of arbitration and the place of voting may not be the same under international commercial arbitration law, although under the New York Convention the place of voting is the same as the place or place of

1 - Holtzman\&neuhaus(2002) A Guide to the UNCITRAL Model law on international commercial arbitration, p.29.

2 - Ibide, 2002. 
arbitration (according to Article 551 of the Convention). International arbitration is perceived which must be assumed to be the place of voting is the place of arbitration. ${ }^{1}$ However, the latter condition is unique in that it is absolutely dependent on the will of the parties and allows it to be easily and arbitrarily subject to international arbitration. It may be considered that such a provision is contrary to legal principles, while with The principles contained in the UNCITRAL Model Law are not even incompatible with Iran's international commercial arbitration law.Because it is based on the principle of the rule of will, in addition, one of the most important principles governing the Model Law and the International Commercial Arbitration Law of Iran is that the parties can determine the law governing arbitration, so that arbitrators do not have the right to deviate from it. Consider formal and substantive issues in accordance with the law selected by the parties and issue an appropriate ruling.In any case, the model law with such a regulation has expanded the scope of international arbitration because each of the above communication factors has caused the separation of the arbitration relationship with a particular country and in fact normally causes conflict of laws that must be resolved to resolve that law. Found the ruler. ${ }^{2}$ However, our Transitional Law in International Commercial Arbitration Law 76 does not pay attention to the criteria and standards in the UNCITRAL Model Law and only pays attention to the criteria and criteria of citizenship that are not considered by the Model Law at all and recognizes it as the only criterion for international arbitration. Article 1 (b) provides: International arbitration means that one of the parties at the time of concluding the arbitration agreement is not a citizen of Iran under Iranian law.

As can be seen, the Arbitration Law of Iran also takes into account the parties, but not in terms of place of business or residence or residence, but only in terms of different nationalities of the parties.Therefore, according to the above regulation, if one of the parties has different citizenship at the time of concluding the arbitration agreement and not at the time of concluding the original contract (which of course may be simultaneous or different), it will be international arbitration.

As a result, even if the seat of arbitration or the place of business of the parties or the residence of the parties who have Iranian citizenship is not in Iran, the arbitration will not be international, even if one of the parties has dual citizenship.Therefore, our legislator has severely limited the scope of international arbitration by imposing such a regulation. Thus, the number of people who will not be able to enjoy the benefits of arbitration is high, and this is actually an obstacle to investment and economic growth.However, mere arbitration and arbitration in each country has economic and social benefits, and national and domestic policies and laws related to international commercial arbitration are in fact the result of the economic policies and issues of each society. ${ }^{3}$ Although the UNCITRAL model law and arbitration rules of many countries do not make the citizenship of the parties the criterion, some countries still involve citizenship along with other elements of influence. The United Kingdom Arbitration Act 1996, which provides in paragraph 85 (2) (a):

The arbitration agreement is considered domestic or national if the parties are not non-English nationals or are not permanently resident outside the United Kingdom. ${ }^{4}$ As it has been said, our legislator in the International Commercial Arbitration Law 76 only pays attention to the criterion and standard of citizenship which is not explicitly mentioned in the model law and recognizes it as the only criterion of international arbitration and this criterion is related to the parties as the model law Arbitration has also considered one of the criteria of the parties, which is the place of business or residence of the parties.In this respect, our law is not far from the model law. It is clear that the model law, based on the common law system, considers a place of residence or a place of business, and the Iranian legislature has used citizenship as a criterion for its localization and compliance with other legal regulations and standards, which is one of the aspects related to the parties.Finally, it should be noted that if one of the parties has different nationality at the time of the agreement, the arbitration will be international, not national, although any dispute, whether civil procedure law or international commercial arbitration law 76, governs It gives an international description to domestic credit and is a domestic judgment, and may be described as foreign in the courts of foreign countries.Therefore, according to the above regulation, if one of the parties has different citizenship at the time of concluding the arbitration agreement and not at the time of concluding the original contract (which of course may be simultaneous or different), it will be international arbitration. As a result, even if the arbitration headquarters or commercial residence of the Iranian nationals is not in Iran, it will not be an international arbitration.

\footnotetext{
1 - Robert H.smit, WIPO Arbitration Rules, newyork,2000.Klower, p.15.

2 - Foucharad, gaillard, goldmanm,International commercial arbitration, Kluwer low, London, 1999, p.84.

3 - RedfernAlen and M.Hunter(2009), Law and practis of international commercial, p.11.

4 - Foucharad, gaillard, goldmanm,International commercial arbitration, Kluwer low, London, 1999, p.56.
} 
Conclusion

Almost all laws and regulations of countries try to distinguish between domestic or national arbitration and international commercial arbitration. Although the existence of the least communication factor that causes conflict of laws indicates the need for international commercial arbitration, for this reason, the UNCITRAL model law has tariffed a large number of communication factors that are subject to international arbitration for countries, but The distinction between national arbitration and international arbitration, contrary to the UNCITRAL Model Law, is achieved simply by the different nationalities of the parties.In other words, the legislator has introduced citizenship as the only communication factor that causes the inclusion of Iran's international commercial arbitration law. This causes most arbitrations to be subject to national arbitration, but the verdict may be considered an internal or external vote, and in any case will not be the governing law of international commercial arbitration law, so that the parties will not be able to agree on a commercial arbitration law. Rule Iran instead of national arbitration and take advantage of the benefits of Iran's international commercial arbitration law. In addition, foreign arbitration is not the same as international arbitration. On the contrary, it is considered domestic arbitration unless the arbitral award is issued in a foreign country.

\section{Resources}

1- Jafari Langroudi, Jafar (2006) Terminology of Law, Treasure and Knowledge, Tehran.

2- Junidi, Laia (2013) Execution of foreign commercial arbitration rulings, its mayor, Tehran.

4- Dehkhoda, Ali Akbar, (1996) Dehkhoda Dictionary, University of Tehran Press.

5- Davani, Ali (139) History of Islam, Haghayegh Publications, Qom.

6- Sidi, Javad, 2013, An Introduction to Referendum Ability in International Commercial Arbitration, Jangal Publications, First Edition, Tehran.

7- Karimi, Abbas, Parto, Hamidreza, (2012) Internal Arbitration Law, Nashrdadgostar, Tehran.

8- Kalantarian, Morteza (1995) Arbitration: A Study of the Most Important Legal Arbitration Systems in the World, Legal Services Office of the Islamic Republic, Tehran.

9- Fayumi, Ahmad (1993) Mesbah Al-Munir, Dar Al-Hijra Publications, Qom.

10- Qaraati, Mohsen (2009) Tafsir Noor, Cultural Center for Quranic Lessons, Tehran.

11- Matin Daftari, Ahmad, (1970) Civil and Commercial Procedure, Volume One, Tehran.

12- Mafi, Homayoun and Parsafar, Javad (2012) Courts' Involvement in Arbitration Proceedings in Iranian Law, Quarterly Journal of Judicial Perspectives, Year 17, No. 57.

13- Mafi, Homayoun, 2016, A Commentary on the International Commercial Arbitration Law of Iran, University of Judicial Sciences and Administrative Services First Edition, Tehran.

14- Maraghi, Seyyed Mir Abdolfattah (Mirfatah Maraghei), 2021, Al-Anawin Al-Faqih, Volume 2: Islamic Publications Office of Qom Seminary.

15-Nikbakht, Hamidreza, 2007, International Commercial Arbitration "Arbitration Rite", published by the Institute of Business Studies and Research. Tehran.

16-Nasiri, Morteza (1964) Execution of foreign arbitral awards, Mousavi Publications.

17- Mohebbi, Mohsen (1988) Execution of Foreign Arbitration Rulings, Legal Services Office, Tehran.

18-Born, Gary(2014)The law Governing International Arbitration agreement .Singapore academy of law journal .

19-Bond,R Stephen(1989) . How to draftan arbitration clause ,J.Int.Arb.No2,1989.

20-Combpell Black Henry(1968), Blacks Law Dictionary minnessota.

21-Foucharad, gaillard, goldmanm,International commercial arbitration, Kluwer low, London, 1999. 
22-Greenberg, simon and Kee,Chritopherand and Romesh, J , (2010) International commercial Arbitration ,Cambridge university press.

23-Gillard, Emmanuel,\& savage John,(1999),fouchardGillard,goldman on jnternatinal commercial arbitrational,kluwer law international.

24- Kohler Gabrielle Kaufman .Glolalization of arbitral procedure , Vanderbilt journal of transnational law, vol.36,2003.

25-Kristopherkeretetter, which law govwrns the arbitration agreement. www. Markumphries. Co.uk.

26-Lew.j.d.m and ali (2003) comparative international commericaialarbitration .klawer law international.

27-Holtzman\&neuhaus(2002) A Guide to the UNCITRAL Model law on international commercial arbitration.

28-RedfernAlen and M.Hunter(2009), Law and practis of international commercial

arbitration Sweet and maxel.

29-Susler, ouzlem, (2012) JURISDICTION OF ARBITRATION TRIBUNALS: A COMPARATIVE STUDY, La Trobe University Bundoora, Victoria 3086Australia.

30-Vanden Berg(1981), Albertjon,thenewyork arbitration onvention of 1958: towards a uniform judicial interpretation, Kluwer law international.

31-Robert H.smit, WIPO Arbitration Rules , newyork,2000.Klower. 